\title{
EKSISTENSI KAMPUNG LAMA MELALUI KEARIFAN LOKAL DI KAMPUNG BUSTAMAN SEMARANG
}

\author{
The Existence Of The Old Kampung Through Local Wisdom \\ At Kampung Bustaman Semarang
}

Annisa Mu'awanah Sukmawati ${ }^{1}$ dan Nany Yuliastuti²

Diterima: 26 Februari 2016 Disetujui: 13 April 2016

\begin{abstract}
Abstrak: Kampung Bustaman adalah salah satu kampung lama yang terletak di pusat Kota Semarang yang masih tetap bisa eksis. Penelitian bertujuan untuk menemukan faktor yang mempengaruhi eksistensi Kampung Bustaman dan memberikan strategi untuk memperkuat eksistensi Kampung Bustaman melalui kearifan lokalnya. Penelitian dilakukan dengan metode penelitian kualitatif melalui pendekatan studi kasus. Metode pengambilan sampel dilakukan dengan teknik snowball sampling. Analisis dilakukan dengan analisis deksriptif kualitatif yang bertujuan untuk memberikan deskripsi mendalam tentang kondisi eksistensi Kampung Bustaman melalui kearifan lokalnya. Penelitian menunjukan bahwa Kampung Bustaman dapat eksis di tengah pembangunan kota melalui kearifan lokal yang dimiliki. Kearifan lokal telah termanifestasi dalam keseharian masyarakat berwujud artefak fisik, aktivitas ekonomi, tradisi keagamaan, dan kehidupan sosial. Kearifan lokal berupa aktivitas ekonomi telah menjadi jiwa bagi Kampung Bustaman. Keberadaan kambing dan diversifikasi aktivitas terkait perkambingan serta usaha kuliner yang digeluti warga ternyata mampu menghidupkan ruang kampung dan juga menjadi jiwa bagi sebagian besar warga Bustaman. Kearifan lokal yang dimiliki juga terus mengalami penguatan sejalan dengan perkembangan zaman dan peningkatan kebutuhan warga yang membutuhkan keberadaan ruang dan adanya peran berbagai pihak untuk menguatkannya.
\end{abstract}

Kata kunci: kampung lama, eksistensi, kearifan lokal, Kampung Bustaman

\begin{abstract}
Kampung Bustaman is an old kampong in the center of Semarang City that still can exist. The research aims to find the factors that influence the existence of Kampung Bustaman and to give the strategy to strengthen the existence of Kampung Bustaman through its local wisdom. The research was conducted using qualitative research with case study approach. The sampling technique used is snowball sampling. Analysis was conducted using descriptive qualitative analysis which aims to provide in-depth descriptions of the conditions of existence of Kampung Bustaman through local wisdom. The results shows that Kampong Bustaman still able to exist in the middle of urban development using local wisdom. Local wisdom has manifested in the daily life, consist of physical artifacts, economic activity, religious traditions, and social life. Local wisdom in the form of economic activity has been the spirit for the Bustaman's occupants. The existence of the diversification activities related to the goats and culinary business that was involved Bustaman's occupants were able to enliven kampung space condition and the most of Bustaman's occupants. Local wisdom possessed also continued to strengthen in line with the times and the increasing need for people who require the existence of space and the role of the various parties to reinforce it.
\end{abstract}

Keywords: old kampong, existence, local wisdom, Kampung Bustaman

${ }^{1}$ Magister Pembangunan Wilayah dan Kota, Fakultas Teknik Universitas Diponegoro Semarang
2 Departemen Perencanaan Wilayah dan Kota, Fakultas Teknik Universitas Diponegoro Semarang

Korespondensi: annisa.muawanah@gmail.com 


\section{PENDAHULUAN}

Kampung lama sebagai embrio perkembangan kota memberi identitas dalam perjalanan perkembangan. Namun saat ini, keberadaan kampung-kampung lama yang terletak di kawasan pusat kota rentan mengalami tekanan, baik tekanan secara fisik dan non-fisik terkait dengan dinamika masyarakat yang menghuni kampung lama tersebut (Suliyati, 2012). Dalam banyak kasus di Kota Semarang, kampung-kampung lama banyak yang hilang. Faktor ekonomi adalah salah satu penyebab eksistensi kampung lama tersebut menjadi hilang (Subagyo, 2014).

Kampung Bustaman adalah salah satu kampung lama di pusat Kota Semarang yang masih mampu eksis di tengah pembangunan Kota Semarang. Eksisnya Kampung Bustaman dilatarbelakangi oleh kemampuan warga lokal kampung untuk bertahan hidup dengan mengembangkan perikehidupan di dalam kampungnya sebagai cara untuk menghidupkan kampung. Kehidupan yang ada di dalam kampung tidak terlepas dari nilai-nilai kehidupan yang diwariskan dari para orang tua mereka terdahulu dan terwujud dalam bentuk fisik, tradisi, dan aktivitas masyarakat. Terkait dengan aspek kesejarahan, Kampung Bustaman juga memiliki korelasi sejarah dengan Raden Saleh, yang tak lain adalah cucu dari Kyai Kertoboso Bustam sang pendiri Kampung Bustaman. Kampung Bustaman juga memiliki keunikan dengan identitasnya sebagai "kampung kambing" karena di dalam kampung terdapat berbagai aktivitas masyarakat terkait kambing, seperti penyembelihan kambing, pembersihan kepala kambing, pemasakan gulai kambing, bahkan adapula kandang kambing di dalam kampung.

Meskipun masih mampu eksis di tengah kota, Kampung Bustaman dihadapkan pada masalah keterbatasan ruang kampung serta dinamika masyarakat yang terjadi di dalam Kampung Bustaman. Dari rumusan masalah tersebut maka muncul pertanyaan penelitian mengapa dan bagaimana kampung lama Bustaman dapat tetap eksis di tengah pembangunan kota? Adapun tujuan penelitian adalah untuk menemukan faktor yang menentukan eksistensi Kampung Bustaman.

\section{METODE PENELITIAN}

Penelitian dilakukan dengan metode penelitian kualitatif dengan pendekatan studi kasus. Melalui pendekatan studi kasus peneliti berupaya untuk mengeksplorasi mengapa dan bagaimana kampung lama masih mampu eksis di tengah pembangunan kota dengan mengambil wilayah studi kasus pada sebuah kampung lama di Kota Semarang, yaitu Kampung Bustaman. Dalam penelitian digunakan teknik sampling yakni snowball sampling. Jumlah informan yang didapatkan selama kegiatan pengumpulan data sebanyak 16 informan. Metode pengumpulan data dilakukan dengan metode pengumpulan data primer, berupa wawancara semi tersrtuktur, observasi lapangan dan audio visual berupa foto dan video dan pengumpulan data sekunder dengan menggunakan telaah dokumen.

Analisis dilakukan dengan menggunakan teknik analisis deskriptif kualitatif. Analisis dimulai dengan memberikan deskripsi tentang kearifan lokal yang dimiliki Kampung Bustaman, pemanfaatan ruang di Kampung Bustaman sebagai aktivitas masyarakat, peran serta masyarakat, pemerintah dan pihak lain untuk Kampung Bustaman hingga akhirnya dapat dirumuskan tentang faktor yang menentukan eksistensi Kampung Bustaman.

\section{HASIL DAN PEMBAHASAN}

\section{Potret Kampung Bustaman Sebagai Kampung Lama Kota Semarang}

Kampung Bustaman adalah salah satu kampung lama kota yang terletak di RW III, Kelurahan Purwodinatan, Kecamatan Semarang Tengah, Kota Semarang. Kampung 
Bustaman memiliki luas wilayah sekitar 0,6 Ha dan terdiri atas 2 wilayah RT, yaitu RT 04 dan RT 05. Peta lokasi Kampung Bustaman terlihat di gambar 1. Kampung Bustaman memiliki jumlah penduduk sebanyak 366 jiwa atau $114 \mathrm{KK}$ dengan jumlah penduduk lakilaki sebanyak 189 jiwa dan perempuan sebanyak 177. Rata-rata jumlah orang per KK di Kampung Bustaman adalah 3-4 jiwa/KK dengan jumlah KK yang menghuni setiap satuan rumah rata-rata sebanyak 2-4 KK/rumah. Kepadatan penduduk di Kampung Bustaman mencapai 610 jiwa/Ha dan tergolong sebagai permukiman berkepadatan sangat tinggi. Kampung Bustaman masih didominasi oleh warga berusia produktif, yaitu antara 15-60 tahun sekitar $65 \%$ dari total jumlah penduduk.

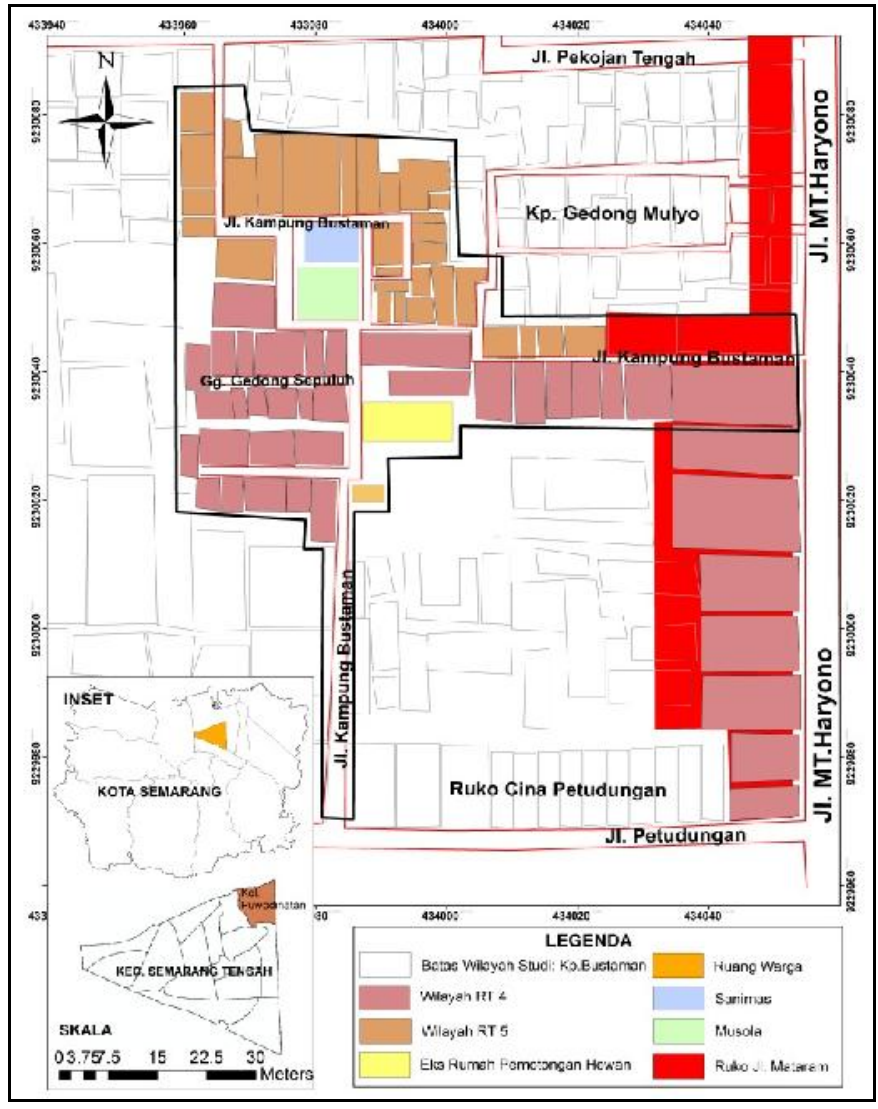

Sumber: Hasil Analisis, 2015

Gambar 1. Wilayah Studi: Kampung Bustaman Semarang

Kondisi prasarana di Kampung Bustaman rata-rata sudah dalam kondisi baik, seperti jalan lingkungan kampung yang sudah dipaving dan sumber air bersih dari sumur dan PAM. Namun untuk drainase kondisinya buruk. Di dalam kampung juga terdapat beberapa sarana yang biasa digunakan warga untuk melakukan berbagai aktivitas, yaitu sanimas (sanitasi berbasis masyarakat), balai warga, musola, dan ruang warga.

Dilihat dari tingkat pendidikannya, penduduk Kampung Bustaman masih memiliki tingkat pendidikan yang rendah dimana sekitar $27 \%$ penduduk hanya tamatan SD, $18 \%$ penduduk tamatan SMP, dan 21\% penduduk tamatan SMA. Ini dikarenakan cara pandang orang tua yang kurang mengutamakan urusan pendidikan anak-anaknya. Meskipun begitu, kehidupan sosial antar warga Bustaman dicirikan dengan kehidupan yang guyub rukun dan 
saling tolong-menolong. Ini dikarenakan antar warga memiliki ikatan ketetanggaan dan ikatan kekerabatan. Berbagai kegiatan sosial keagamaan masih terdapat di Kampung Bustaman, seperti PKK untuk Ibu-Ibu, santunan kematian, kerja bakti, kegiatan TPQ untuk anak-anak. Kampung Bustaman juga memiliki perkumpulan remaja bernama Ikatan Remaja Bustaman (IRB) serta paguyuban warga bernama forum guyub warga yang menampung aspirasi warga Bustaman dalam lingkup 2 RT.

Kampung Bustaman didominasi oleh penduduk yang bermatapencaharian sebagai swasta, pelajar, buruh, dan Ibu rumah tangga. Geliat kehidupan ekonomi di Kampung Bustaman berlangsung hampir selama 24 jam. Sejak pagi pukul 02.00 hingga sebelum subuh aktivitas pemotongan kambing sudah nampak di kampung ini. Sekitar pukul 06.30 para bakul pengambil daging dan jeroan kambing mulai berdatangan ke Kampung Bustaman. Pukul 09.00 hingga sore hari aktivitas kuliner harian oleh warga lokal Bustaman berlangsung di dalam kampung. Setelah maghrib, mulai masuk penjual makanan keliling dari luar kampung yang menjajakan makanan hingga tengah malam.

\section{Kearifan Lokal Bagi Eksistensi Kampung Lama}

Kampung lama merupakan bagian dari permukiman perkotaan yang dibentuk oleh konsep keruangan dalam kurun waktu yang sangat lama dan muncul secara spontan sehingga jaringan prasarana kurang memadai. Kampung lama menjadi salah satu komponen pembentuk struktur kota yang muncul terlebih dahulu sebelum proses perencanaan sehingga kampung berkembang secara organis serta minim penyediaan infrastruktur (Wijanarka, 2007). Sementara itu, kearifan lokal merupakan usaha manusia untuk bertindak dengan menggunakan akal budinya terhadap sesuatu dengan pengetahuan lokal dimiliki pada ruang tertentu (Ridwan, 2007).Bagi suatu permukiman, kearifan lokal membentuk pola dan struktur ruang kampung lama, dimana nilai-nilai kearifan lojal terwujud dalam bentuk adat istiadat, tradisi, bahasa, kehidupan sosial yang guyub, dan sistem nilai dalam berperikehidupan yang telah diwariskan secara turun temurun (Madiasworo, 2009).

Kampung lama yang masih eksis hingga saat ini menggambarkan bahwa kampung memiliki kemampuan untuk bertahan dari masa ke masa, dimana interaksi antara manusia dengan ruang kampung dan aktivitas yang ada di dalamnya tidak bisa dipisahkan. Putra (2013) mengungkapkan bahwa eksistensi kampung mencerminkan bagaimana kampung kota mampu bertahan (surviva) di tengah pembangunan perkotaan modern dengan nilainilai yang ada dalam kehidupan masyarakat lokal sebagai hasil interaksi manusia dengan ruang kampung, aktivitas yang dilakukan, dan latar belakang sosial budaya.

Kearifan lokal memberi makna tersendiri bagi keberadaan sebuah kampung lama di tengah kota. Kearifan lokal tidak hanya mencerminkan identitas lokal suatu kawasan kampung atau sekelompok masyarakat, namun juga dapat meningkatkan kondisi perekonomian masyarakat lokal. Melalui langkah revitalisasi kearifan lokal, suatu citra kawasan kampung lama dapat dibangkitkan. Kampung lama yang sarat akan kesejarahan, kebudayaan, tradisi lokal yang menunjukan ciri khas budaya lokal dapat dijadikan peluang untuk mengesksiskan kampung melalui aktivitas pariwisata kreatif yang di dalamnya terdapat upaya untuk mengkolaborasikan antara nilai ekonomi dengan daya jual untuk wisata dan budaya (Panich et al, 2014; Mustika \& Apriliani, 2013). Dari segi kebijakan, langkah untuk memasukan unsur kearifan lokal dalam kebijakan penataan ruang perlu dilakukan. Ini karena kampung-kampung lama kota memiliki nilai memori tersendiri dalam sejarah perkembangan kota (Ernawi, 2010). 


\section{Eksistensi Kampung Lama Bustaman Melalui Kearifan Lokal}

Analisis terhadap kondisi eksistensi Kampung Bustaman dilakukan dengan memberikan pemahaman mendalam secara deskriptif terhadap kearifan lokal yang dimiliki oleh Kampung Bustaman, pemanfaatan ruang di Kampung Bustaman, peran masyarakat, pemerintah dan pihak lain untuk eksistensi Kampung Bustaman. Hasil analisis dari masingmasing sasaran tersebut akan menghasilkan temuan studi dari tentang mengapa dan bagaimana Kampung Bustaman dapat eksis di tengah pembangunan kota.

\section{Kearifan Lokal Kampung Bustaman}

Kampung Bustaman adalah salah satu kampung lama di Kota Semarang yang memiliki kearifan lokal yang diwariskan secara turun temurun dan kini termanifestasi ke dalam wujud aktivitas ekonomi masyarakat, artefak fisik, tradisi, dan kehidupan sosial masyarakat sebagai warisan budaya yang patut dilestarikan. Berikut penjelasannya:

Aktivitas ekonomi yang ada di Kampung Bustaman terkait dengan identitas kampung kampung kambing karena mewarisi usaha berdagang kambing sejak zaman kolonial. Hingga saat ini, diversifikasi aktivitas terkait perkambingan ada di dalam Kampung Bustaman, mulai dari kegiatan penyembelihan kambing, pemotongan kambing menjadi bagian-bagian tertentu, pengolahan bahan kambing menjadi kuliner seperti gulai, sate, tongseng, pembuatan dan penjualan bumbu-bumbu untuk masakan kambing, dan transaksi jual beli terkait perkambingan lainnyadilakukan di dalam kampung, bahkan ditemukan pula tempat penyimpanan kambing di dalam kampung. Sementara itu, warga yang tidak memiliki keterampilan dalam aktivitas ekonomi terkait perkambingan, menopang kehidupan ekonomi dengan berjualan kuliner harian di dalam kampung. Geliat kehidupan ekonomi warga berbasis pada kambing dan olahan kuliner inilah yang menjadi jiwa aktivitas keseharian warga Bustaman.

Kampung Bustaman masih memiliki beberapa peninggalan artefak fisik yang memiliki nilai sejarah. Meskipun sudah mengalami perubahan bentuk bangunan dan tidak mencerminkan kondisi aslinya, namun beberapa bangunan tersebut masih memiliki memori tersendiri bagi warga Bustaman. Artefak fisik yang dimiliki oleh Kampung Bustaman berupa musola yang ada sejak zaman Belanda, sanimas Pangrukti Luhur yang merupakan eks MCK kuno Belanda, cagak listrik kayu yang dibangun tahun 1938dan beberapa rumah berciri tradisional Jawa dan jengki. Peninggalan artefak fisik tersebut hingga saat ini juga masih digunakan sebagai ruang aktivitas warga. Beberapa rumah kuno tersebut juga masih dijadikan sebagai tempat tinggal.

Tradisi keagamaan yang masih dilestarikan oleh warganya hingga saat ini, seperi tradisi-tradisi menjelang puasa Ramadhan, seperti Gebyuran Bustaman dan doa bersama (nyadran), kegiatan rutin saat Bulan Ramadhan (solat teraweh berjamaah, tadarusan, dan jaburan puasa Ramadhan dengan ciri khasnya bubur jangan), pengajian, syawalan, dan peringatan hari-hari keagamaan umat Islam, seperti Isra Mi'raj, maulidan, dan lainnya. Tradisi keagamaan masih dilestarikan hingga saat ini sebagai wujud penghormatan warga terhadap nilai keagamaan yang telah diwariskan oleh para orang tua terdahulu.

Kehidupan sosial masyarakat Bustaman dicirikan dengan kehidupan sosialnya yang guyub rukun karena ada ikatan ketetanggaan dan kekerabatan.

Kearifan lokal tersebut memiliki nilai lokalitas dan menjadi identitas masyarakat Kampung Bustaman. Meskipun berada di tengah kehidupan perkotaan modern, kearifan lokal yang masih dipertahankan hingga saat ini mencerminkan bahwa ada keinginan dari masyarakat Bustaman untuk melestarikan warisan budaya para orang tua mereka terdahulu. Disamping berfungsi sebagai upaya untuk mempertahankan hidup masyarakat, kearifan lokal yang dimiliki juga menjadi strategi untuk mempertahankan eksistensi kampung di tengah pembangunan kota karena melalui kearifan lokal tersebut kampung 
dapat tetap menggeliat aktivitasnya disamping meningkatkan kondisi kehidupan sosial, ekonomi dan spiritual warga Bustaman. Penguatan kearifan lokal dilakukan dengan cara mengimplementasikan dan terus melakukan serta mewariskan tradisi dan kebiasaan ke generasi penerus. Kondisi ini sejalan dengan ungkapan (Ernawi, 2010) bahwa kearifan lokal dapat bertahan jika mampu menyesuaikan degan perkembangan zaman dan diperkuat kondisinya sejalan dengan interaksi manusia dengan lingkungannya.
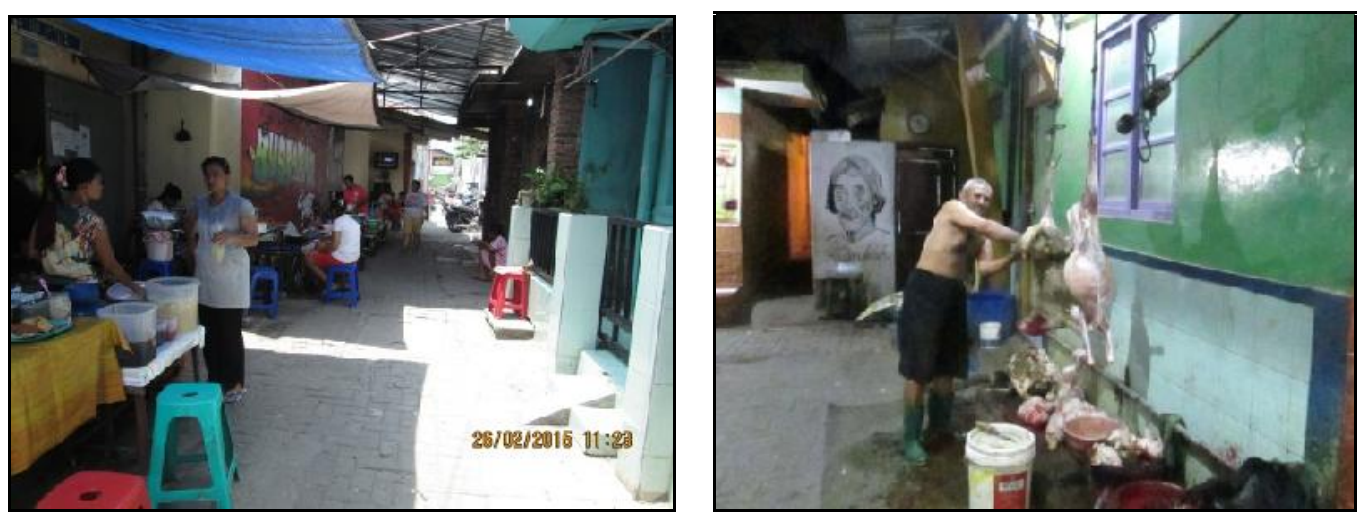

Sumber: Hasil Observasi Lapangan, 2015

Gambar 2. Deretan Penjaja Kuliner Harian Di Dalam Kampung Bustaman (kiri) dan Penyembelihan Kambing Pada Dini Hari (kanan)

Lebih lanjut, hasil analisis terhadap kondisi kearifan lokal di Kampung Bustaman menunjukan kearifan lokal berwujud aktivitas ekonomi memiliki signifikansi baik untuk memperkuat eksistensi Kampung Bustaman. Aktivitas ekonomi yang dimaksud terkait dengan aktivitas perkambingan dan keberadaan penjaja kuliner harian. Melalui geliat kehidupan ekonomi di dalam Kampung Bustaman setiap harinya, ruang dan warga kampung dapat bertahan hidup. Kearifan lokal berwujud aktivitas ekonomi mencerminkan keterampilan lokal warga Bustaman. Keberadaan kegiatan perdagangan kambing di dalam Kampung Bustaman yang telah ada sejak zaman kolonial dan masih berlangsung hingga sekarang telah memberi identias bagi Kampung Bustaman sehingga Bustaman dikenal sebagai kampung kambing. Diversifikasi aktivitas terkait perkambingan ini juga muncul di dalam kampung. Kambing yang menjadi komoditas basis warga Bustaman telah mampu memberi lapangan kerja tersendiri bagi sebagian warga Bustaman seperti jagal, tukang kelet, dan membersihkan kepala kambing berasal dari warga lokal Bustaman sendiri. Sedangkan mengolah masakan menjadi kuliner telah menjadi strategi tersendiri bagi sebagian besar warga Bustaman untuk memenuhi kebutuhan hidupnya. Begitu pula dengan gulai kambing bustaman yang telah menjadi ciri khas kuliner Bustaman dan terus diupayakan untuk dilestarikan.

\section{Pemanfaatan Ruang Kampung Bustaman}

Kampung Bustaman sebagai permukiman lama memiliki beberapa ruang yang biasa dimanfaatkan oleh warga sebagai ruang aktivitas. Di tengah keterbatasan ruang kampung, warga didorong untuk dapat memaksimalkan setiap ruang yang ada guna menunjang aktivitasnya. Dikaitkan dengan potensi kearifan lokal yang dimiliki oleh Kampung 
Bustaman berupa aktivitas ekonomi berbentuk warisan berdagang kambing dan diversifikasi aktivitas terkait perkambingan serta kuliner harian, warga Bustaman memiliki caranya tersendiri dalam memanfaatkan setiap jengkal ruang yang ada sebagai ruang ekonomi warga. Berikut ini adalah wujud pemanfaatan ruang kampung dikaitkan dengan aktivitas ekonomi yang dilakukan di dalamnya. Gambar 3 menggambarkan peta persebaran fungsi ruang di Kampung Bustaman dikaitkan aktivitas ekonomi yang terjadi di dalamnya.

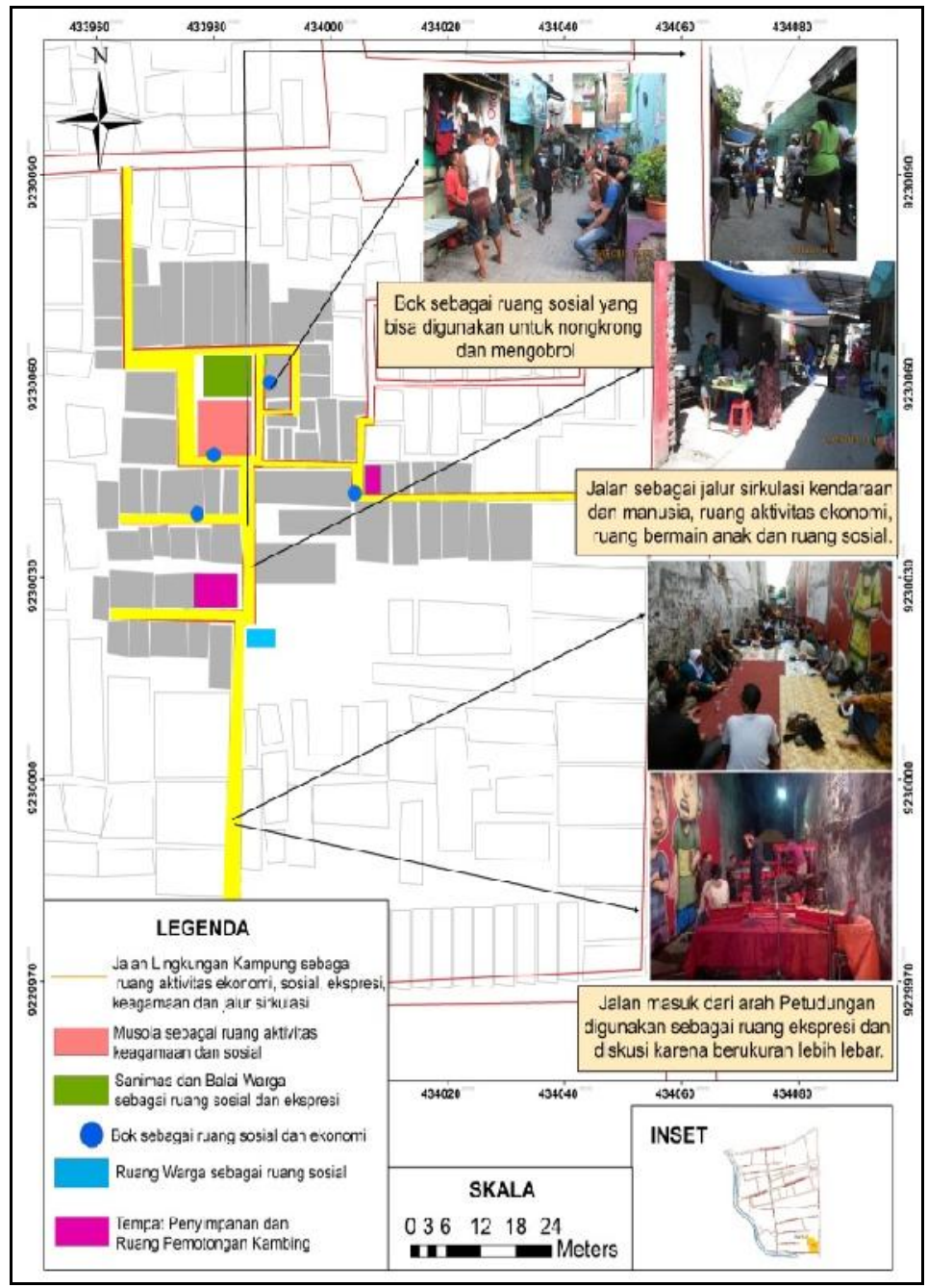

Sumber: Hasil Analisis, 2015

Gambar 3. Peta Persebaran Fungsi Ruang Untuk Aktivitas Ekonomi di Kampung Bustaman

Dalam menunjang aktivitas ekonomi, keberadaan ruang-ruang di Kampung Bustaman mampu dioptimalkan pemanfaatannya oleh warga Bustaman, yaitu warga asli Bustaman dan warga pendatang. Warga asli Bustaman merupakan penduduk Bustaman yang sudah menetap di Kampung Bustaman sejak lahir dan masih mewarisi aktivitas ekonomi dari para orang tua terdahulu, baik aktivitas terkait perkambingan maupun menjual kuliner. Sedangkan warga pendatang adalah para boro yang bertempat tinggal di dalam Kampung Bustaman. Hal ini sejalan dengan ungkapan Doxiadis (1968) bahwa 
permukiman dapat hidup karena ada keterpaduan antara contain yang menyangkut manusia dengan segala aktivitas yang dilakukannya dengan container yang menyangkut wadah dimana aktivitas itu terjadi. Serupa dengan Sujatini et al (2015) yang mengungkapkan bahwa ada kaitan antara ruang, waktu dan aktor. Begitu pula dengan Kampung Bustaman yang ternyata dapat hidup karena adanya manusia, aktivitas, ruang kampung, dan diferensiasi waktu kehidupan aktivitas. Di dalam Kampung Bustaman sendiri terjadi fenomena waktu dan ruang dalam satu wilayah kampung, dalam artian bahwa beragam aktivitas terkait ekonomi terjadi di dalam Kampung Bustaman dengan aktor/ pelaku aktivitas yang berbeda (tabel 1)

\section{Peran Serta Masyarakat, Pemerintah dan Pihak Lain bagi Eksistensi Kampung Bustaman}

Dalam upaya mengeksiskan Kampung Bustaman tidak terlepas dari perlunya peran serta masyarakat, pemerintah dan pihak lain. Adapun kontribusi atau wujud peran serta masing-masing pihak bagi eksistensi Kampung Bustaman terlihat dalam skema di gambar 4

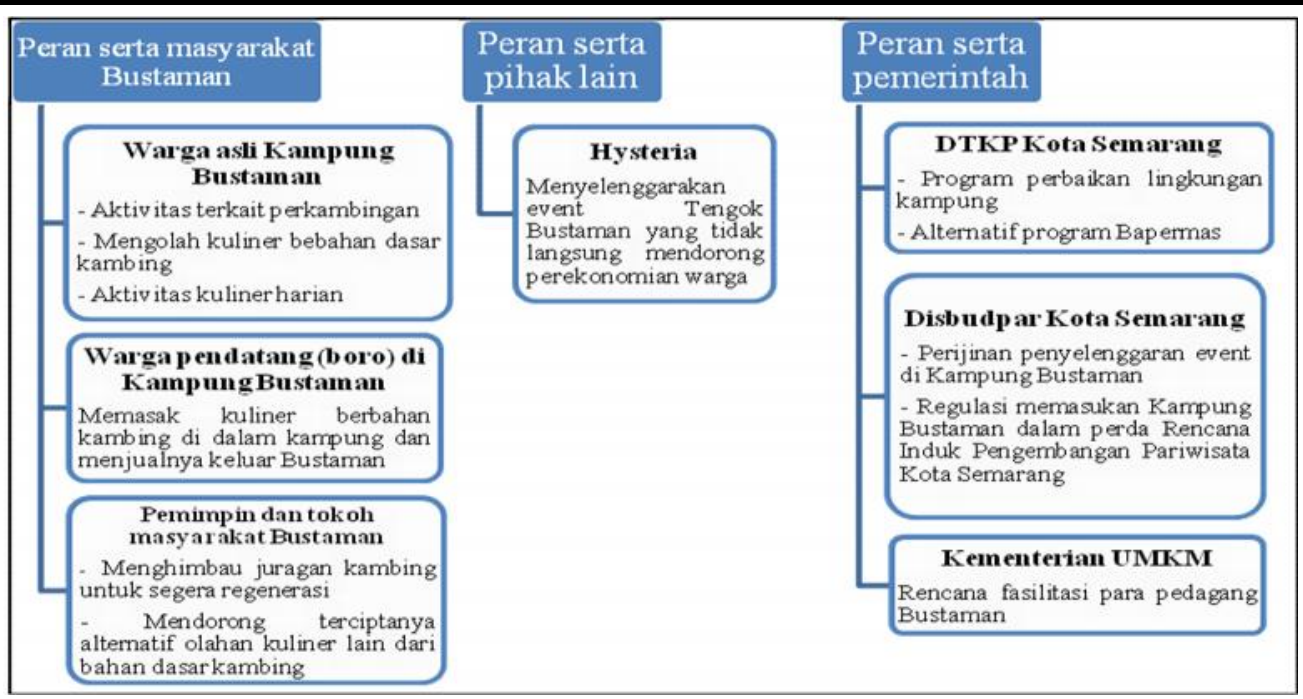

Sumber: Hasil Analisis, 2015

Gambar 4. Peran Serta Masyarakat, Pemerintah dan Pihak Lain Untuk Eksistensi Kampung Bustaman

Tabel 1. Pelaku Ekonomi, Aktivitas Ekonomi Yang Dilakukan, dan Ruang yang Digunakan

\begin{tabular}{|c|c|c|c|}
\hline Aktor & $\begin{array}{l}\text { Wujud Aktivitas } \\
\text { Ekonomi }\end{array}$ & Pemanfaatan Ruang & Keterangan \\
\hline \multirow{5}{*}{$\begin{array}{l}\text { Warga } \\
\text { Bustaman }\end{array}$} & $\begin{array}{ll}\text { Pemotongan } & \text { kambing, } \\
\text { pengkeletan } & \text { kambing, } \\
\text { pembersihan jeroan } & \end{array}$ & $\begin{array}{l}\text { Tempat pemotongan } \\
\text { hewan sementara } \\
\text { Jalan lingkungan kampung }\end{array}$ & $\begin{array}{l}\text { Setiap hari antara pukul } \\
03.00-05.00\end{array}$ \\
\hline & $\begin{array}{l}\text { Pemotongan kambing menjadi } \\
\text { bagian kecil, pembersihan } \\
\text { kepala kambing }\end{array}$ & Jalan lingkungan kampung & $\begin{array}{l}\text { Setiap hari antara puku } \\
05.30-07.00\end{array}$ \\
\hline & Kuliner harian & Jalan lingkungan kampung & $\begin{array}{l}\text { Setiap hari antara pukul } \\
09.00-16.00\end{array}$ \\
\hline & Memasak kuliner kambing & Rumah & $\begin{array}{l}\text { Kondisional (jika ada } \\
\text { pesanan/ catering) }\end{array}$ \\
\hline & Pembuatan & Rumah & Setiap hari di pagi hari \\
\hline
\end{tabular}




\begin{tabular}{|c|c|c|c|}
\hline Aktor & $\begin{array}{l}\text { Wujud Aktivitas } \\
\text { Ekonomi }\end{array}$ & Pemanfaatan Ruang & Keterangan \\
\hline $\begin{array}{l}\text { Warga } \\
\text { pendatang } \\
\text { (boro) }\end{array}$ & $\begin{array}{l}\text { penjualan bumbu gule kambing } \\
\text { Memasak dan menjual kuliner } \\
\text { kambing bustaman, seperti gulai } \\
\text { bustaman keluar kampung }\end{array}$ & $\begin{array}{l}\text { Rumah boro untuk tempat } \\
\text { memasak kuliner kambing } \\
\text { bustaman }\end{array}$ & $\begin{array}{l}\text { Setiap hari } \\
\text { Penjaja gule (antara } \\
\text { pukul 05.30-09.00) } \\
\text { Penjaja sate dan } \\
\text { tengkleng (antara pukul } \\
09.00-17.00 \text { ) }\end{array}$ \\
\hline
\end{tabular}

Sumber: Hasil Analisis, 2015

\section{KESIMPULAN}

Kampung Bustaman dapat tetap eksis di tengah pembangunan kota karena memiliki keunikan. Keunikan yang dimiliki Kampung Bustaman berupa kearifan lokal yang termanifestasi dalam kehidupan sehari-hari warga Bustaman. Kearifan lokal yang dimiliki oleh Kampung Bustaman mencerminkan strategi warga Bustaman untuk mempertahankan kehidupan masyarakat dan ruang kampung dari tekanan pembangunan kota. Manifestasi kearifan lokal yang terlihat saat ini merupakan hasil interaksi antara manusia dengan ruang kampung yang terjadi dalam kurun waktu lama dan diwariskan secara turun temurun.

Kearifan lokal yang dimiliki oleh Kampung Bustaman merupakan hasil interaksi antara manusia dengan ruang kampung yang mencerminkan strategi warga Bustaman dalam mempertahankan hidup. Kearifan lokal mampu memberi jiwa bagi kehidupan Kampung Bustaman melalui implementasinya dalam keseharian warga berwujud aktivitas ekonomi, kehidupan sosial, tradisi keagamaan, dan peninggalan artefak fisik. Kearifan lokal berwujud aktivitas ekonomi memiliki dampak signifikan bagi eksistensi Kampung Bustaman saat ini dan di masa mendatang. Ini dikarenakan saat ini, Kampung Bustaman dapat tetap hidup melalui geliat aktivitas ekonomi sehari-hari yang terjadi di dalam kampung, baik yang dilakukan oleh warga asli Bustaman maupun warga pendatang (boro). Tidak hanya memberi jiwa bagi kehidupan masyarakat, namun juga memberi jiwa bagi hidupnya ruang-ruang kampung. Ruang-ruang kampung dapat hidup melalui ragam aktivitas ekonomi yang terjadi karena ruang berguna dalam menunjang keberlangsungan aktivitas ekonomi.

Adanya hubungan timbal balik antara aktivitas ekonomi sebagai kearifan lokal dan ruang karena ruang dapat hidup akibat aktivitas dan aktivitas juga memerlukan ruang sebagai wadahnya. Di dalamnya juga tidak terlepas oleh adanya para aktor baik dari masyarakat setempat, pemerintah dan pihak lain yang menggunakan ruang sebagai tempat beraktivitas dan berupaya mendorong atau men support eksistensi kearifan lokal agar dapat terus berlanjut. Di sisi lain, langkah pemanfaatan ruang yang dilakukan merepresentasikan bagaimana upaya mereka untuk bisa tetap bertahan hidup di tengah kondisi ruang yang terbatas namun tetap bisa melakukan aktivitas keseharian yang telah menjadi kebiasaan dan warisan ini. Sementara itu, kearifan lokal berwujud aktivitas ekonomi juga dapat hidup karena adanya dukungan dari berbagai pihak untuk menjaga kelestariannya.

\section{DAFTAR PUSTAKA}

Doxiadis, C.A. 1968. Ekistics: An Introduction to the Science of Human Settlement. London: Hutchinson and Co.

Ernawi. 2010. Harmonisasi Kearifan Lokal dalam Regulasi Penataan Ruang. [Home page of Direktorat Jenderal Penataan Ruang Departemen Pekerjaan Umum] [Online]. Available at: http://penataanruang.net/taru/upload/paper/sinkronisasikearifanlokal_300410.pdf. Diakses pada 18 Maret 2015.

Madiasworo, T.. 2009. "Revitalisasi Nilai-Nilai Kearifan Lokal Kampung Melayu Semarang dalam Pembangunan Berkelanjutan.” Jurnal Local Wisdom, Vol. 1.1, pp.10-18. 
Mustika, M.D.S dan Putu D. Apriliani. 2013. Analisis Faktor-Faktor yang Mempengaruhi Kebertahanan Pedagang Kuliner Tradisional di Kabupaten Klungkung. Jurnal Kuantitatif Terapan, Vol. 6.2, hal. 119127.

Nasution, Ivan K. dan Mediatrich Triani. 2012. “Kecerdasan Ruang Marjinal dan Potensi Ruang Publik.” Proceding Temu Ilmiah IPLBI, hal. 21-24.

Panich, Winita, Thirachaya M., Taksina K., Thongphon Promasaka N.S. 2014. "Management Strategy of Cultural Tourism: A Case Study of Sakon Nakhon Province, Thailand.” Asian Social Science, Vol. 10.5, pp. 48-54.

Putra, Budi A.. 2013. “The Survival Phenomenon of Kampong Kuningan Amidst the Development of Mega Kuningan Business-area in Jakarta.” International Journal of Scientific \& Engineering Research, Vol.4.1, pp.1-6.

Ridwan, Nurma Ali. 2007. “Landasan Keilmuan Kearifan Lokal.” Ibda’, Vol. 5.1, hal. 27-38.

Subagyo. 2014. Tiga Kampung Kini Tinggal Kenangan. [Home Page of Koran Wawasan] [Online]. Available at: http://www.koranwawasan.com/02/05/2014/tiga-kampung-kini-tinggal-kenangan/. Diakses pada tanggal 17 Maret 2015.

Sujatini, Siti, Tresna P. Soemardi, Abimanyu T.A, Linda D. 2015. “Temporary Public Open Space as a Spatial Product on Social Life of City Kampong Community, Jakarta." IACSIT International Journal of Engineering and Technology, Vol. 7.2, pp. 156-159.

Suliyati, Titiek. 2012. Dinamika Kawasan Permukiman Etnis di Semarang. [Home Page of Institutional Repository of Diponegoro University] [Online]. Available at: http://eprints.undip.ac.id/34046/1/Dinamika_Kaw.Etnis_di_Semarang.doc. Diakses pada tanggal 21 Maret 2015.

Wijanarka. 2007. Semarang Tempo Dulu: Teori Desain Kawasan Bersejarah. Yogyakarta: Penerbit Ombak. 